\title{
DISPERSAL OF WILD SUNFLOWER BY SEED AND PERSISTANT BASAL STALKS IN SOME AREAS OF CENTRAL ITALY
}

\author{
Vischi, M. ${ }^{1^{*}}$, Cagiotti, M.E. ${ }^{2}$, Cenci, C.A. ${ }^{3}$, \\ Seiler, G.J. ${ }^{4}$ and Olivieri, A.M. ${ }^{1}$ \\ ${ }^{1}$ Dip. Scienze Agrarie ed Ambientali, Università di Udine, Via delle Scienze, 208, \\ I 33100 Udine, Italy \\ 2 Dip. Biologia Vegetale e Biotecnologie, Università di Perugia, Borgo XX \\ Giugno, 74, I 06121 Perugia, Italy \\ ${ }^{3}$ Dip. Biologia ed Economia Agraria, Università di Udine, Via del Cotonificio, 28, \\ I 33100 Udine, Italy \\ ${ }^{4}$ USDA - ARS, Northern Crop Science Laboratory, Fargo, ND 58105, USA
}

Received: September 15, 2005

Accepted: December 05, 2006

\section{SUMMARY}

In some sites of Central Italy wild sunflowers are spreading from marginal areas into cropped fields. Crops like maize, tomato, tobacco, alfalfa are often infested with wild sunflowers. Hybrid sunflower crops are also infested with wild material. Plants and populations of wild sunflower also spontaneously grow at the edge of the fields, and along the ditches and roads. We have observed that wild sunflower is partially dispersed by its seed, but possibly it can propagate vegetatively by its perennial basal stalk when it survives the mild winter seasons. We have evidence that sunflower seeds maintain germination capacity for years after being plowed into the soil.

This wild sunflower phenotypically resembles $H$. annuus, but the strong root system is not usual for an annual sunflower species. Concerning its origin, we observed variations indicating naturalization by either an introgression process involving wild species or a segregation of a hybrid variety and the enrichment of genes conferring seed dispersion and root persistence. It is possible that a similar process occurred a few centuries ago, after its introduction to Europe when sunflower escaped botanical gardens and began to colonize Eastern European areas.

Key words: wild sunflower, seed dispersal, introgression, invasiveness

* Corresponing author: Phone: +39 0432 558609, Fax: +39 0432 558603;

e-mail: massimo.vischi@uniud.it 


\section{INTRODUCTION}

Since 1986 some crop areas of Central Italy have been severely infested by wild sunflower, particularly where the sunflower crop has been grown repeatedly over the years (Monotti and Bonciarelli, 1992). Cagiotti et al. (1994) found invasive sunflowers in rural areas and along roads and ditches in Perugia and surrounding locations. Both authors identified this invasive species as Helianthus annuus.

Because of the long sunflower tradition and its importance in Italy, we observed this new weedy relative to find out how it was dispersed and to ascertain its origin. We were also interested to see if this material had any useful agronomic traits, such as the perennial habit, that could be utilized in further breeding programs aimed at production on marginal areas.

\section{MATERIAL AND METHODS}

Wild sunflower surveys were done during the last eight years in cultivated fields of the Umbria region around Perugia, San Martino in Campo, San Martino in Colle, Badiola, Agello, Corciano, Magione, Umbertide, and Città di Castello. Careful observations were carried out during spring and summer 2003, 2004 and 2005 on plant invasiveness, plant morphology with particular attention to branching, root structure, leaf pigmentation, phyllaries and seed dispersion.

Mature heads, sampled in populations coming from the first four locations were studied for seed retention at the University of Udine. The number of seeds shattering and those remaining attached to the inflorescence were counted after vigorously shaking a single head.

\section{RESULTS AND DISCUSSION}

Wild sunflower plants infested summer crops of maize, sugar beet, tomato, tobacco, and hybrid sunflower. In early summer, plants with a small, single inflorescence and $20-30 \mathrm{~cm}$ in height emerged in fields where barley and durum wheat were harvested 1-2 months before. In December 2003, plants of the weedy sunflowers also developed flowers in alfalfa forage crops. Invasive sunflowers were found in fields where sunflower has not been cultivated for more than 5 years.

Wild plants grew scattered at the moist edges of arable fields where tillage and herbicide treatments were limited or absent. Plants also grew spontaneously along the ditches and at the edges of main roads and motorways. Sometime they formed naturalized populations with plants of different age due to the non-uniform seed germination, typical of wild species.

Wild sunflower spontaneously grew in an undisturbed patch close to San Martino in Colle for at least 2-3 years. At the beginning of August 2004, an extreme variability in plant height, from 30 to $310 \mathrm{~cm}$, was observed as a partial consequence 
of an extended period of seedling emergence and plant development. Almost all plants were branched according to the four categories given by Seiler (1997) and Miller and Fick (1997). Rare plants exhibited a unique head resembling cultivated sunflower. Red pigmentation was usually observed on stem and branches and sometime up to the main leaf venation. Leaf shape and size were variable within the same plant, as usually in cultivated sunflower. Some plantlets had the first pair of leaves shaped similar to those of $H$. bolanderi and $H$. argophyllus (Figure 1 ). In any case, at maturity, the plants also had considerable pubescence and floral traits, such as phyllaries and paleas, which would classify them as wild Helianthus annuus.

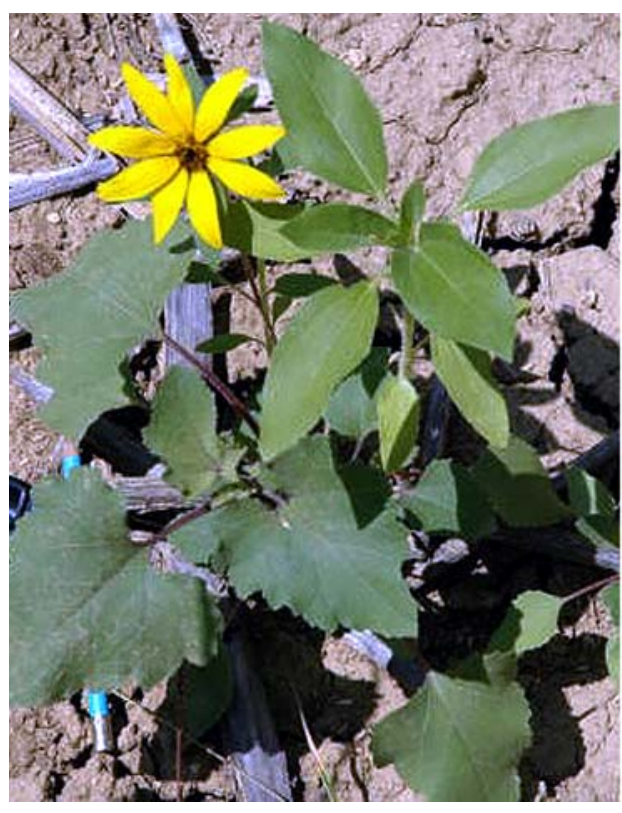

Figure 1: Leaf variation in seedlings of wild sunflowers

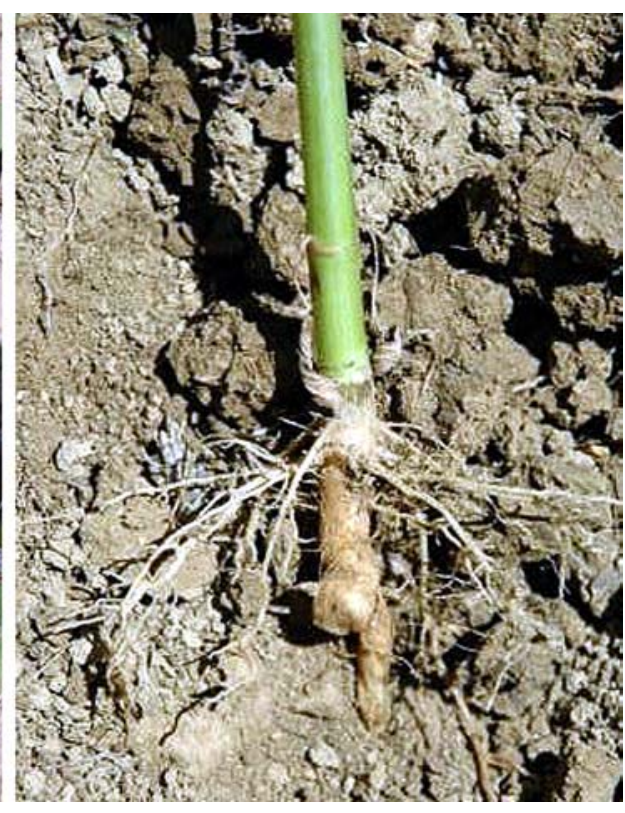

Figure 2: Sunflower plant with rhizome-like structure

However, a different conclusion could be drawn when one looked at the roots. Normally, sunflower plants develop from seeds with a primary root surrounded by secondary roots, and typically they are annuals (Seiler, 1997). Most plants we observed had rhizome-like roots with an almost perennial structure, shaped differently and emerging from below soil (Figure 2). Some rhizomes appeared as broken parts of an original one. Soil tillage could have contributed to vegetatively propagating these plants. Further analysis is required to know whether those were true rhizomes or a perennial basal stalk with easy rooting ability as reported by Rogers et al. (1984). In any case, no tubers were present, even though $H$. tuberosus was growing naturally in close proximity (Cagiotti et al., 1999). 
The experiment concerning seed retention in mature heads showed seed dispersion ranging from 0 to $60 \%$. However, only few heads (less than $5 \%$ out of the sampled plants) had complete seed retention. No difference was found between the central and lateral heads on the same plant, nor between single-head type plants and branched ones. Seed dehiscence, being one of the first traits selected in plant domestication, would be observed as a consequence of hybridization with a wild species or of very different growing and environmental conditions in respect to those in which the sunflower genotype was originally selected (Olivieri, 1999).

Concerning the origin of such material, we believe that a Helianthus annuus crop variety was introgressed with genes from a foreign species, possibly a perennial species. Many sunflower species are compatible with $H$. annuus (Rogers et al., 1982; Jan, 1997) even though they lack a flowering period overlapping, are incompatible or have irregular chromosome pairing. In this particular case we do not know what species are involved, but it has been suggested (P. Vannozzi, personal communication) that a few wild species arrived from the U.S.A with hybrid seed stocks. The leaf morphology of sampled plants shows differences from the cultivated sunflower (Figure 1). Seed pigmentation also suggests gene enrichment with genes of wild sunflower. Seed from some plants appears with small dots ("speckles") typical of wild species, but it remains difficult to ascertain a putative parent. In addition to this hypothesis, segregants from hybrid varieties would be naturalized in that area characterized by particular environmental conditions. We cannot rule out the possibility of a mutation and/or the recombination of $H$. annuus with adventitious roots such as reported by Rogers et al. (1984). Molecular markers may be able to help us understand the origin of this sunflower.

For breeding purposes a perennial or almost-perennial $H$. annuus represents a genetic resource for yield potentiality in marginal areas.

Pollen dispersion of this wild sunflower around a high oleic fatty acid hybrid crops can actually affect the fatty acid composition of the cultivated sunflower. However, further evaluation will have to be carried out to learn what the impact on oil quality could be.

\section{REFERENCES}

Cagiotti, M.R., Ranfa, A., and Romano, B., 1994. Sulla presenza di specie nuove e/o in espansione in aree antropiche di Perugia e del lago Trasimeno. Giornale Botanico Italiano 128(1): 204.

Cagiotti, M.R., Ranfa, A., Marinangeli, F., and Maovaz, M., 1999. Invasive species in urban and suburban coenosic in central Italy. In: $5^{\text {th }}$ Intl. Conf. Ecology of Invasive Alien Plants, La Maddalena, Sardinia, Italy, 13-16 October 1999, pp.1-2.

Jan, C.C., 1997. Cytology and Interspecific Hybridization. In: A.A.Schneiter (ed.). Sunflower Technology and Production. ASA, CSSA, and SSSA, Madison, WI, USA, pp. 497-558.

Monotti, M., and Bonciarelli, U., 1992. Infestation of wild Helianthus annuus in cultivated sunflower in Italy: Origin, spread and control. In: Proc. ANPP $15^{\text {th }}$ Columa Conference, Intl. Meeting on Weed control, Versailles, France, 2-4 December, pp. 701-707. 
Olivieri, A.M, 1999. New traits observed in sunflower grown in unusal environmental conditions. In: Proc. Symposium Sunflower and Other Oilseed Crops in Developing Countries, Maputo, Mozambique, February 9-12, pp.180-186.

Rogers, C.E., Thompson, T.E., and Seiler, G.J., 1982. Sunflower species of the United States. Natl. Sunflower Assoc., Bismarck, North Dakota, USA, pp. 75.

Rogers, C.E., Unger, P.W., and Kreitner, G.L., 1984. Adventitious rooting in "Hopi" sunflower: Function and anatomy. Agron. Jour. 76: 429-434.

Seiler, G.J., 1997. Sunflower anatomy and morphology. In: A.A. Schneiter (ed.). Sunflower Technology and Production. ASA, CSSA, and SSCA, Madison, WI, USA, pp. 67-111.

Seiler, G.J., and Rieseberg, L.H., 1997. Systematics, origin, and germplasm resources of the wild and domesticated sunflower. In: A.A. Schneiter (ed.). Sunflower Technology and Production. ASA, CSSA, and SSCA, Madison, WI, USA, pp. 21-65.

\title{
DIVULGACIÓN DEL GIRASOL SILVESTRE POR SEMILLA Y POR LA PARTE BASAL DEL TALLO EN ALGUNAS PARTE DE ITALIA CENTRAL
}

\author{
RESUMEN
}

En algunas localidades de Italia Central, el girasol silvestre se divulga desde las partes colindantes en los campos de producción. Los cultivos como maíz, tomate, tabaco y alfalfa a menudo son infectadas del girasol silvestre. Las plantas y poblaciones de girasol silvestre individuales, crecen espontáneamente en los bordes de campos, al lado de zanjas y caminos. Hemos observado que el girasol silvestre se divulga parcialmente mediante semilla, pero también resulta posible divulgarse vegetativamente de la raíz perenne, cuando éste sobrevive invierno templado. Tenemos a nuestra disposición las pruebas de que la semilla de girasol mantiene la habilidad de germinación, años después de que la semilla fuera arada profundamente en el suelo.

Este girasol silvestre recuerda fenotípicamente a $H$. annuus, pero el sistema de raíces robusto no es característica habitual de las especies de girasol anuales. En cuanto al origen, hemos notado la variación, lo que indica la adaptación de la recién llegada especie silvestre o la segregación de alguna variedad o híbrido y su enriquecimiento con genes que trasmiten la capacidad de reproducción de vía generativa, tanto como de vía vegetativa. Es posible que el proceso semejante se haya desarrollado hace unos siglos, también, tras introducción del girasol en Europa, cuando el girasol escapó de los jardines botánicos y empezó a poblar las regiones de Europa del Este.

\section{PROGAGATION DU TOURNESOL SAUVAGE PAR LES GRAINES ET LA BASE DE LA TIGE DANS CERTAINES PARTIES DE L'ITALIE CENTRALE}

\author{
RÉSUMÉ
}

Dans certaines localités de l'Italie centrale, le tournesol sauvage se propage depuis les environs aux champs de culture. Les cultures comme le maïs, la tomate, le tabac et la luzerne sont souvent infestées de tournesol sauvage. Les plantes et les populations de tournesol poussent spontanément au bord des champs et le long des fossés et des routes. Nous avons remarqué que le tournesol sauvage était partiellement propagé par ses graines mais il peut aussi être propagé végétativement par la base de sa tige persistante lorsqu'elle survit 
au cours d'hivers cléments. Nous avons les preuves que les graines de tournesol gardent leur aptitude à germer pendant des années après avoir été enfouies dans la terre par les labours.

Du point de vue du phénotype, le tournesol sauvage ressemble au $H$. annuus, mais un système de racines vigoureux n'est pas une caractéristique habituelle des espèces annuelles de tournesol. Pour ce qui concerne l'origine, nous avons remarqué des variations qui indiquent une acclimatation soit par un processus d'introgression impliquant des espèces sauvages, soit par la ségrégation d'une variété hybride et un enrichissement des gènes provoquant la propagation des graines et la persistance de la racine. Il est possible qu'un processus similaire ait eu lieu il y a quelques siècles, après l'introduction du tournesol en Europe lorsque celui-ci s'est échappé des jardins botaniques et a commencé à coloniser les régions de l'Europe de l'Est. 